\title{
Creation of Parameter Sets for Exploration of Environmental Effects on the Course of Disease
}

\author{
Zigurds Markovics ${ }^{1}$, Ieva Markovica ${ }^{2},{ }^{1,2}$ Riga Technical University
}

\begin{abstract}
The paper is devoted to the research problems, when influence of external environmental factors on healthy organism or the course of the disease is required. One of the first problems is to decide, what body parameters should be measured to evaluate most important impact factors. The easiest way is to measure everything that can be measured, or to use only in practice applied measurements. However, the result is better if the set of parameters is purposefully selected, based on the efficiency parameters and overlapping all disease affected subsystems providing coverage of all pathogenic manifestations of the disease. The authors suggest for this purpose to use the topological modeling of pathogenesis, formalized model processing, parameter evaluation, ranking and selection of parameters using the table overlay method.
\end{abstract}

Keywords-Coverage, disease pathogenesis, environmental factors, expert evaluation, organism, topological model.

\section{INTRODUCTION}

Any biological system is composed of elements that are linked by structural, functional and informative links, which provide a functional unity of the system [1], [2]. Such biological system is also a human body. The united system is located in the environment to which it is bounded with substances, energy and information exchange. Variety of environmental factors can lead to equally diverse effect on the body's elements. Exposition to one of the elements of the external environmental factors causes also changes in the functioning of other elements. This is evidenced by both the normal physiology of the organism [2] and the pathological physiology (sick organism) studies [3], [4].

Environmental factors can act on the body by improving the functioning of resources, or on the contrary - worsen and even stop its functioning [5], [6], [7].

With external environmental factors here you can understand both natural and man-made artificial fields of different origin.

1) Natural fields:

- $\quad$ Solar radiation [8];

- Ultraviolet radiation [9];

- Radiation produced in bowels of the earth, granite rocks;

- Earth's magnetic field (global and local) [10], [11], [12];

- Environmental sound field [13], etc.

2) Artificial fields:

- Emission of radiation in nuclear power plants [14];

- High-power and super-high voltage power line eletromagnetic fields;

- Microwave oven generated field;
- Electromagnetic field produced by control scanners at airports, supermarkets and MRI systems in hospitals [15];

- X-ray radiation during imaging procedures, computed tomography, etc. [16];

- Electromagnetic radiation from radars, mobile phone base stations [17], [18], [19].

The proposed research aims to clarify Earth's magnetic field (background and local) influence on human cardiovascular system (CVS). It is proposed to start with a narrow task of studying the magnetic field (MF) influence on the CVS of single pathology patients, namely, the arterial hypertension $(\mathrm{AH})$ patients.

\section{PRoBlem STATEMENT}

Three main tasks should be solved to reach the postulated aim: 1. To study the effect of environmental factors on the biological system, it is necessary to find out a set of system parameters for which values or their changes can be judged on environmental factors, potency and spectrum. The selected set of parameters is further referred as the measured parameter set (MPS).

2. To find the MPS set, a mathematical model suitable to solve this task must be developed.

3. Huge observational and experimental work must be done to capture the relationship between the environmental factors and main characteristics of the biological system.

This article deals only with the first two tasks.

The MPS set can be defined by a number of requirements, such as liability, coverage, measurement options, etc.

\section{Relationship.}

Sets of elements should be closely associated with the living organism under the study processes, in other words, they must be in causal connection with the body's processes.

2. Coverage.

The parameter set must cover all body's processes inherent in the surveyed area (must be necessary and sufficient).

3. Scalability.

The parameter element set should be measurable and technical, the measuring cost and time should be as low as possible, efficiency of results must be as high as possible. Thus, an action group has some discrepancy of parameters that should be followed up in the selection procedures.

In practice, the known number of the measured parameter set selection methods are used by various challenges, such as pattern recognition, differential diagnostics, forecasting, etc.

Let us look at some of the most popular methods for parameter selection. 


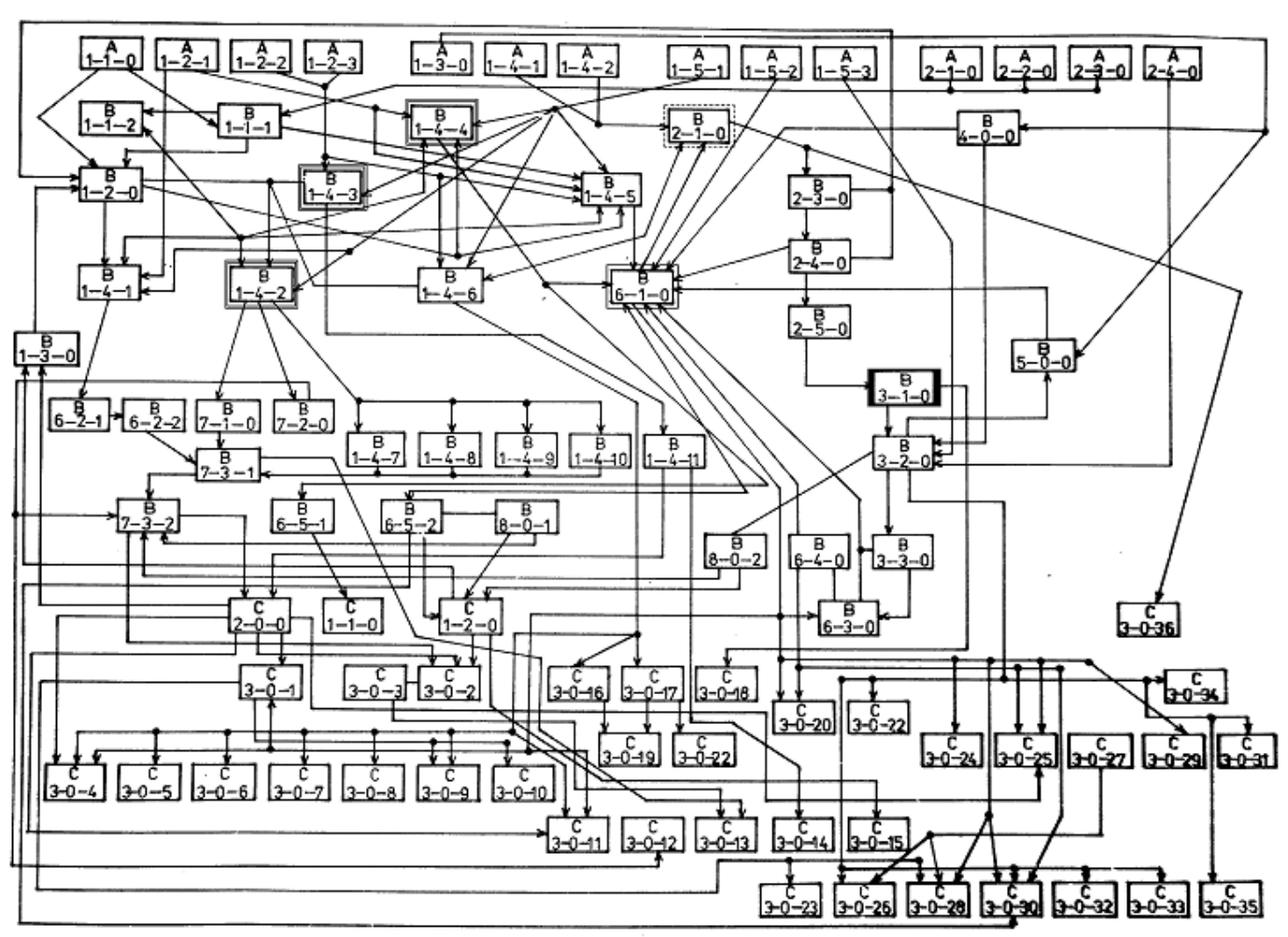

Fig. 1. AH topological model.

Method 1) An arbitrary set of parameters includes voluntary traditional, accepted by praxis by well-known parameters and measuring instruments.

Positive qualities: transparency, intelligibility, relatively low price.

Negative qualities: fragmentary information, which does not cover all issues, the possibility of fragmented information base to create erroneous conclusions about the problem as a whole.

Method 2) Measured parameters are taken together with all known and measurable parameters, especially without exploring how they relate to the research problem in a given system.

Positive qualities: credibility of the removal of fragmentary information.

Negative qualities: large measuring volume, relatively high costs. However, the biggest concern is the rapid increase in the noise level generated by the problem of non-parametric presence. The fact is that formal algorithms for further processing also these "strangers" hanging the parameters of quality indicators, e.g., Diagnostic scales, especially in the case of statistical calculation, rather interfere with the proper diagnosis than help.

Method 3) All parameters are calculated quality indicators (performance indicators). Parameters are arranged in a row (or ranked) and the measured parameters include total queue elements.

Positive qualities: there is a guarantee that the result set will enter only the best parameters which can partially satisfy the coverage requirements.

Negative qualities: the requirements of necessity and sufficiency are not satisfied.
Method 4) The group is a selection of a set of quasi-optimal parameters. This group also includes the author's coating method of the developed tables for the selection of diagnostic parameters which can be adapted also for the task at issue is the case.

The parameter adjustment of the line provides the best representation of penetration of the result set, the table provides coverage finding of necessity and adequacy requirements.

However, the result is better if the set of measurable parameters is purposefully selected, with account of the efficiency of parameter, a link to the affected subsystems, providing coverage of all pathogenic disease manifestations [20].

In the case of the mathematical model that we offer to adapt, the previous topological modeling has proven itself to biological systems and medical diagnostic and therapeutic problems of choice.

\section{MATHEMATICAL MODEL OF THE PROCESS}

The offered MPS selection methodology is based on a heterogeneous system of topological modeling principles [21], in particular the topological models in biology and medicine [22].

The topological model (TM) represents the disease pathogenic mechanisms of the disease-causing and contributing factors to the manifestations of the disease symptoms. The model is plotted in the form of a graph where nods are the above-mentioned forms, but arcs - cause and effect link between these expressions.

Arterial hypertension in the pathogenic mechanism of the topological model is shown in Fig. 1 and nods transcript fragment is given in Table I [22]. 
TABLE I

NODS OF AH TOPOLOGICAL MODEL

\begin{tabular}{|c|c|c|}
\hline Level & Designation & Name \\
\hline 1. & 2. & 3. \\
\hline $\begin{array}{l}\text { A etiologies } \\
\text { and predis- } \\
\text { posing } \\
\text { factors }\end{array}$ & $\begin{array}{l}\text { A } 1.1 .0 \\
\text { A } 2.1 .0 \\
\ldots\end{array}$ & $\begin{array}{l}\text { blood pressure (BP) regulatory nerve } \\
\text { center of hyperactivity } \\
\text { emotional overload }\end{array}$ \\
\hline $\begin{array}{l}\text { B regulatory } \\
\text { mechanisms } \\
\text { deviations }\end{array}$ & $\begin{array}{l}\text { B } 1.1 .2 \\
\ldots \\
\text { B } 1.4 .2 \\
\text { B } 1.4 .3 \\
\ldots \\
\text { B } 2.3 .0 \\
\ldots \\
\text { В } 3.3 .0 \\
\ldots \\
\text { B } 6.5 .2 \\
\ldots \\
\text { B } 7.3 .1 \\
\ldots\end{array}$ & $\begin{array}{l}\text { adrenal function abnormalities } \\
\text { cardiac hyper } \beta \text { adrenergy } \\
\text { large arterial hyper } \alpha \text { adrenergy } \\
\text { increased synthesis of angiotensin I } \\
\text { arteriolar changes in the structure } \\
\text { increased total peripheral resistance } \\
\text { systolic volume increase }\end{array}$ \\
\hline $\begin{array}{l}\text { C clinical } \\
\text { symptoms }\end{array}$ & $\begin{array}{l}\text { C } 1.2 .0 \\
\text { C } 2.1 .0 \\
\text { C } 3.0 .1 \\
\ldots \\
\text { C } 3.0 .4 \\
\ldots \\
\text { C } 3.0 .10 \\
\ldots \\
\text { C } 3.0 .12 \\
\ldots \\
\text { C } 3.0 .18 \\
\ldots\end{array}$ & $\begin{array}{l}\text { elevated diastolic BP } \\
\text { elevated systolic BP } \\
\text { central nervous system vascular spastic } \\
\text { changes } \\
\text { pulsation in the head } \\
\text { dizziness } \\
\text { heart rate > } 80 \text { beats / minute } \\
\text { elevated aldosterone levels in the blood }\end{array}$ \\
\hline
\end{tabular}

Model nodes are presented on 3 levels:

1) Level A features the disease causing factors;

2) Level $B$ depicts the body and changes in functioning subsystem of organs;

3) Level $\mathrm{C}$ represents the clinical manifestations or symptoms (Fig. 2).

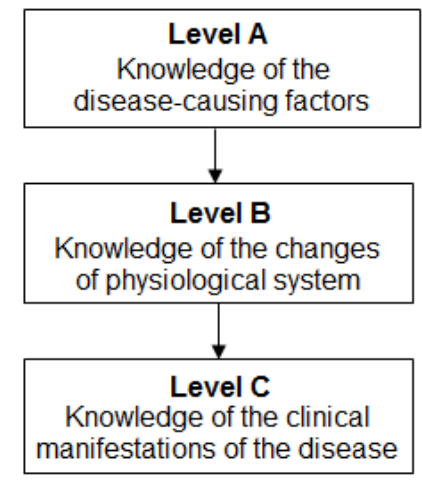

Fig. 2. Knowledge levels of pathogenesis.

External environmental factors in the system model can be represented as yet unidentified arrows acting in the model of peaks in Level A and B. The challenge is to find the arrow application points, nod exposure and spectrum, on the condition that the measured parameter set MPS postulates Level C.

This means that the measured set of MPS requirements apply to such AH pathological process variables as closeness and coverage.

Certainly, specific changes in the functioning of the body's subsystems in practice are known as disease names. The nods of Level B, which represent the specific pathological features and replace the name of the disease, are known as the disease code nods (DCN).

Speaking about the disease code nods, AH has its specifics.

At $\mathrm{AH}$ arterial blood pressure (BP) in a given range of values is held in a complex physiological regulatory system. Arterial hypertension (AH) in the case of BP inadequately elevated, is causing damage to organs and maintains several pathogenetical mechanisms (PM). These have been further explored:

1) adrenergic $P M_{1}$, when elevated $B P$ maintains the sympathetic nervous system hyperreactivity;

2) the rennin-dependent $\mathrm{PM}_{2}$, when elevated BP maintains active substance renin angiotensin II, a potent vasoconstrictor;

3) aldosterone-dependent $\mathrm{PM}_{3}$, when the active substance aldosterone changes the water and salt balance in the body by increasing the circulating plasma volume and vascular wall thickness;

4) previous PM-induced vascular changes in the inner wall lead to the next - structural $\mathrm{PM}_{4}$ when elevated BP maintains a cross-sectional narrowing of blood vessels, vascular hypertrofying not only internal, but also of smooth muscle.

It should be emphasized that all PM are interrelated. At the same time $\mathrm{AH}$ at different periods can dominate any of them.

The AH topological model includes all the abovementioned blood pressure and supportive regulatory mechanisms, which are denoted by $\mathrm{PM}_{1}-\mathrm{PM}_{4}$. Each of them met in the common area of the graph that illustrates the four regulatory system abnormalities and leads to the same result - high blood pressure. $\mathrm{PM}_{\mathrm{i}}$ is the graph for each of one or more code nods (DCN) (Table II).

TABLE II

Code Nods of Pathogenic MeChanisms

\begin{tabular}{|c|c|c|}
\hline Pathogenic mechanism $\mathbf{P M}_{i}$ & $\mathbf{P M}_{i}$ sou & vertices \\
\hline $\begin{array}{c}\mathrm{PM}_{1} \\
\text { (adrenergic) }\end{array}$ & $\begin{array}{l}\text { B } 1.4 .1 \\
\text { B } 1.4 .2 \\
\text { B } 1.4 .3\end{array}$ & $\begin{array}{ll}\text { B } 1.4 .4 \\
\text { B } 1.4 .5 \\
\text { B } 1.4 .6\end{array}$ \\
\hline $\begin{array}{c}\mathrm{PM}_{2} \\
\text { (renin-dependent) }\end{array}$ & \multicolumn{2}{|c|}{ B 2.1 .0} \\
\hline $\begin{array}{c}\mathrm{PM}_{3} \\
\text { (aldosterone-dependent) }\end{array}$ & \multicolumn{2}{|c|}{ B 3.1 .0} \\
\hline $\begin{array}{c}\mathrm{PM}_{4} \\
\text { (structural) }\end{array}$ & \multicolumn{2}{|c|}{ B 6.4 .0} \\
\hline
\end{tabular}




\section{QuAntitative Assessment OF Elements OF THE MODEL}

The topological model of the disease constitutes a specialist doctor's or expert's opinion. Thus, the TM represents the expertise of the current moment in the disease pathogenesis.

Model nod quantitative assessment methodology is available, known as the pinnacle of weight $\lambda_{i}$ identification [22].

Weight of nod $\lambda_{i}$ represents the parameter "Direct measurement capabilities" and is calculated using the weighted sum method:

$$
\lambda_{i}=\varepsilon_{1} a_{i 1}+\varepsilon_{2} a_{i 2}+\varepsilon_{3} a_{i 3}+\varepsilon_{4} a_{i 4}+\varepsilon_{5} a_{i 5},
$$

where

$a_{i 1}$ rating parameter for measuring availability (after the access capabilities);

$a_{i 2}$ rating parameter for measuring time;

$a_{i 3}$ rating parameter for measuring costs;

$a_{i 4}$ parameter rating by the results of objectivity;

$a_{i 5}$ rating parameter for measuring a traumatic factor;

$\varepsilon_{1}-\varepsilon_{5}$ appropriate evaluation criteria of importance factors,

$$
\sum_{i=1}^{5} \varepsilon_{i}=1 .
$$

All values $a_{i 1}-a_{i 5}$, as well as the importance of the coefficients $\varepsilon_{1}-\varepsilon_{5}$ are determined by an expert evaluation of the experiment, as in most cases raised by the assessment criteria do not allow reviews to make objective numerical values, with the exception of measuring time and measuring costs. Experts in their field as the best specialists serve as subjective instruments for assessing the availability of the measurement parameters, objectivity, and traumatic factors and all weighted criteria.

Expert evaluation method is to postulate that the averaged values of given individual experts may be calculated if and only if the two optional tests are performed, and the results have been positive.

1. Expert opinions coincidence degree examination. This is done with the help of concordation coefficient W [23]. It is based on the Spearman ranking correlation between the sizes of the range $0-1$.

In medicine the smallest threshold value adopted is 0.70 , if the assessment directly affects human life, the underlying valuations lesser threshold value is 0.5 .

2. Calculated $\mathrm{W}$ coefficient for statistical significance test at the Pearson chi square $\left(X^{2}\right)$ criteria.

The lowest threshold value (probability) assumed is 0.95 .

Unfortunately, the weighed sum method has the so-called compensation characteristics of the good rates on one criterion can compensate for low valuations (including nulls) by other criteria. In cases where there are no exclusion criteria, compensation feature is considered as a positive phenomenon.

Exclusion criteria in the case when very low value and null compensation is not allowed, and the formula (1) is not applicable to the original appearance. For example, if a parameter for measuring the availability of $a_{i 1}=0$, other assessments by other criteria become meaningless.
Solving the problem of exclusion criterion is to enter the minimum value of the threshold value. Unless the score is less than the threshold value, it is assumed that the endpoint (vertices) weight $\lambda_{i}=0$.

In the present study, the threshold value adopted $a_{i 1}=0.5$, which represents the biochemical and immunological tests that require special preparation of the patient.

Specific task yielded the following quantitative indicators:

1) the importance of the coefficient values are $\varepsilon_{1}=0.24$, $\varepsilon_{2}=0.13, \varepsilon_{3}=0.07, \varepsilon_{4}=0.28, \varepsilon_{5}=0.28$

2) concordation factor $W=0.653$;

3 ) the statistical reliability (probability) 0.95 ;

4) concordation coefficient values $W$ size $a_{i 1}-a_{i 5}$ expert evaluations of nodes of the graph is in the range of 0.519 to 0.989 , statistical significance is not less than 0.95 .

This means that there is a possibility of expert data to calculate the average value. The particular task is calculated by mathematical expectation given by iterative methods [24].

$$
y_{i k}=\frac{\sum_{j=1}^{m} y_{j i} \exp \left[-\frac{\left(y_{i k-1}-y_{j i}\right)^{2}(m-1)}{2 \sum_{j=1}^{m}\left(y_{i k-1}-y_{j i}\right)^{2}}\right]}{\sum_{j=1}^{m} \exp \left[-\frac{\left(y_{i k-1}-y_{j i}\right)^{2}(m-1)}{\left.2 \sum_{j=1}^{m}\left(y_{i k-1}-y_{j i}\right)^{2}\right]}\right.}
$$

where

$m$ number of experts;

$y_{i j} \quad j$-th expert rating $i$-th object;

$k=1, \ldots ., \mu$ and the process ends at $\mu$ iterations, if $\left|y_{i \mu}-y_{i \mu-1}\right| \leq \delta$; $\delta$ posing mistake of assessment.

The AH topological model nod weights are within $\lambda_{\text {min }}=3,001, \lambda_{\max }=9,432$.

The model links assigned quantitative values - the range of weights $I\left(x_{i} / x_{i+1}\right)$. Range of weight shows that some amount of information about the parameters $x_{i}$ can be obtained if the measured parameter is $x_{i+1}$. Specific diagnostic task is to talk about one of the nodes $x_{i}$ influence on the nod $x_{i+1}$. The graph link from nod $x_{i}$ to nod $x_{i+1}$ indicates that the pathological process (or parameter) $x_{i}$ nod is caused or affected by the pathological process (parameter) $x_{i+1}$. Link weight is expressed in the size of the impact. On the other hand, if the instrument is placed on top $x_{i+1}$, it can be formulated as nod $x_{i+1}$ response in relation to the nod $x_{i}$. If the link weight $I\left(x_{i} / x_{i+1}\right)$ is given a higher value, then $x_{i+1}$ sensitivity is higher. This means small, but still visible to the parameter $x_{i}$ changes are reflected in changes in parameter $x_{i+1}$ link weight $I\left(x_{i} / x_{i+1}\right)$ which is the lowest grade, if at large (the entire range) in parameter $x_{i}, x_{i+1}$ can be determined just visible to the changes.

Weight range of quantitative value, as well as the nod weight of quantitative variables are found by the expert experimental method considering all conditions. 
Range of weight calculation group concordation ratio is in the range $W_{\min }=0.5091, W_{\max }=0.874$, the weight value $I_{\min }=2,745, I_{\max }=9,988$.

Further TM evaluation and calculations are based on the methodology in [22], which is based on the following presumptions:

1. Graph $\mathrm{G}$ with vertex set $X$ and arc set $Q$ vertex $x_{l} \epsilon X$ is reachable from vertices $x_{0} \epsilon X$, if there is even only one routeoriented $P\left(x_{0}, x_{1}\right)$ of vertices $x_{0}$ to the top $x_{i}$;

2. On the route $P\left(x_{0}, x_{l}\right)$ graph $G$ from $x_{0}$ to $x_{l}$ is called the nod $x \in X$ and the range of $q \in Q$ final sequence $P\left(x_{0}, x_{l}\right)=\left(x_{0}, q_{1}, x_{1}, q_{2}, \ldots, q_{l}, x_{l}\right)$. Nod $x_{0}$, which represents one of the disease code nods, known as the route start nod. The nod $x_{l}$, represents the symptom, called the route end nod;

3. Route graph, with $x_{0}=x_{l}$, is called a cycle;

4 . The entire set of routes with the start nod $x_{0}$, belonging to the code of the disease nods in $x_{0} \epsilon d_{c}$ and connecting $x_{0}$ with other nodes of the graph, is called a code of reachability components $P\left(x_{0}\right)$ (Fig. 3). So $P\left(x_{0}\right)$ indicates all of the pathogenic processes that may affect the code nod $x_{0}$;

5. The entire set of routes from the code nodes of the disease under consideration by the end of the summit $x_{l}$ is called $\operatorname{nod} x_{l}$

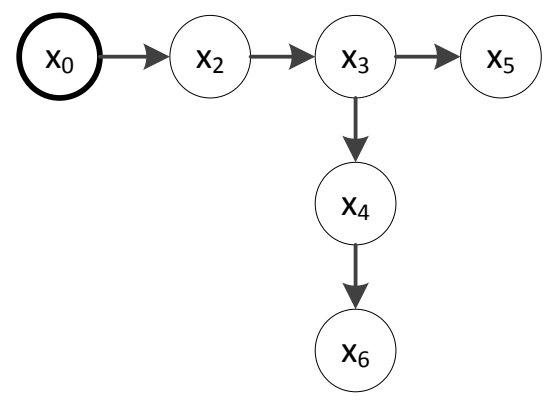

Fig. 3. Reachability component $P\left(x_{0}\right)$.

dependence component $U\left(x_{l}\right)$ (Fig. 4). Thus $U\left(x_{l}\right)$ shows all the code vertices, the disease and the processes that may affect the $\operatorname{nod} x_{l}$.

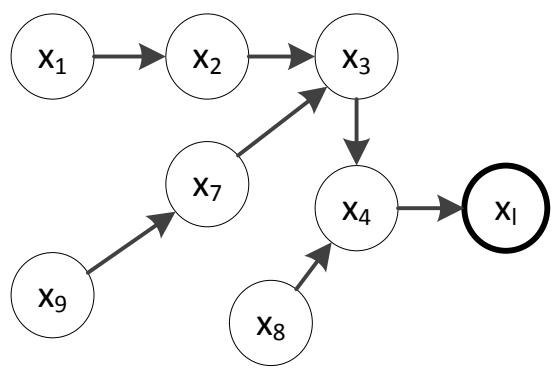

Fig. 4. Dependency component $U\left(x_{l}\right)$.

Components of reach and dependency, as well as the range of weight are estimated using the route distance calculation between the nodes of the graph.

On the route distance $\rho$ (path length) between the estimated graph nod $x_{i}$ and $x_{j}$ is called the value of

$$
\rho\left(x_{i}, x_{j}\right)=\min \sum_{i=1}^{j-1} \bar{I}\left(x_{i} / x_{i+1}\right),
$$

where

$\bar{I}\left(x_{i} / x_{i+1}\right)=I_{\max }+I_{\min }-I\left(\mathrm{x}_{i} / x_{i+1}\right) ;$

$I\left(x_{i} / x_{i+1}\right)$ link weight;

$I_{\max }, I_{\min } \quad$ weight range of the maximum and minimum value for a given task.

The selected value $\bar{I}\left(x_{i} / x_{i+1}\right)$ and the link weight $I\left(x_{i} / x_{i+1}\right)$ place is determined by the link weight loaded content which expresses the closeness of ties, one could also say this, and it is the opposite of the concept of "distance". According to the concept of harmonization metrics obtained $\rho\left(x_{i}, x_{j}\right)$ mean: the greater the distance $\rho$, the weaker the link between the nods.

\section{Choice of Set of Measurable Parameters}

Written at the beginning of the measured parameter set, MPS stipulates the requirements. One of them concerns the parameter links of the strength of the ongoing processes in the body. The strength of ties (closeness) can be treated as a more informative concept, as the amount of information on the nod of $x_{i}$ obtained by measuring the nod $x_{i+1}$.

Informativity can be considered as an indicator, which includes two components. One component of nods $x_{i}$ is the distance $\rho$ from the code nod of the disease. In other words, it is the proximity of the disease parameter code: parameter of closeness, because it is more informative.

The second component is code nod number, from whom parameter is accessible in work graph. Informatively major for nod $x_{i}$ can be expressed as,

$$
\Omega_{i}=\sum_{O=1}^{t} \bar{\rho}\left(x_{i} / x_{o}\right)
$$

where

$t \quad$ code vertices number of peaks which reach vertex $x_{i}$ work with graph $\rho \leq \rho_{k r}$;

$\bar{\rho} \quad$ distance or proximity to the inverse value;

$\bar{\rho}\left(x_{i}, x_{o}\right)=\rho_{k r}+\rho_{\min }-\rho\left(x_{i}, x_{o}\right)$;

$\rho_{k r} \quad$ distance maximum value.

So after computable model parameter $\Omega_{i}$ represents the parameter of informative or necessary to measure degree.

Model nod weight $\lambda_{i}$ represents the parameter measurement capabilities.

These two indicators provide a fairly controversial criterion space; DCN close to the nods standing are more closely associated with the process, so informative, but difficult to measure, or even non-measurable.

Since the task is not to find the best, most efficient nod, but a whole set of nods that cover the whole DCN, the task is divided into 2 parts:

1) calculation of the nod efficiency;

2) finding of DCN coverage.

The effectiveness of nod is 


$$
\Phi_{i}=\alpha \lambda^{*}+\beta \Omega_{i}^{*}
$$

where

$\alpha$ and $\beta$ factors of importance, $\alpha+\beta=1$,

$\lambda_{i}^{*}=\frac{\lambda_{i}}{\lambda_{\max }}, \quad \Omega_{i}^{*}=\frac{\Omega_{i}}{\Omega_{\max }}$.

Values of $\alpha$ and $\beta$ can be found by expert techniques, in particular $\alpha=0.43, \beta=0.57$.

The last step in the quest for a MPS is coverage. A table has been created, where TM peaks are located in the vertical direction, ranked by efficiency ratio $\Phi_{i}$ wear. Horizontally placed are code vertices of the disease, in this case, the pathogenic mechanisms of the AH code vertices. The entry value $\bar{\rho}\left(x_{i}, x_{o}\right)$ with the code peaks according to the component dependency is written in the table body.

MPS composition begins to develop from the peaks ranked in the top row until no code vertices vertex is left uncovered.

This means that the selected set of parameters will provide information on the position of all code nods - regulation of blood pressure in all states of pathogenic mechanisms.

But the code nod is considered to be covered only if its column below in the current line is not at issue $\bar{\rho}$ with a higher value than the viewed one.

Compliance with the essential composition of the MPS provides:

1) ranking parameters for efficiency ratio $\Phi_{i}$, which include measurement capabilities and are more informative;

2) a method table, which ensures the necessity and sufficiency.

The described algorithm for parameter selection constitutes the first round. The second round is associated with the selected set of verification and experimental research. The result of the first round of the discussion on the $\mathrm{AH}$ patient status is identified as a whole with an unknown parameter set. This is without prejudice to specific questions about the external agent exposure specifics.

If the experiment finds that any of the selections are a little sensitive to a specific external environmental agent, this parameter should be replaced by another more sensitive one or permitted to other characteristics of degradation.

\section{CONCLUSION}

1. The parameter set selection method, based on topologic modeling base being proposed and proved in diagnostic task, biological systems established based on the measured parameter set selection method, advocated and demonstrated that the diagnostic task, after appropriate adaptation, is suitable for a new class of tasks - the research of measured parameters for the selection of external environmental factors which impact on the human body and have different origin and the provision of various pathological conditions.

2. Topological modeling of biological systems may be adapted and applied to solve a new class of tasks - tasks of the research of environmental factors an the effect size of various diseases.

3. During the research changes found in parameters under influence of external factors, based on the configuration of the model, allow to determine the change in the prevalence of type-related peaks of the model.

\section{REFERENCES}

[1] R. A. Wallace, Biology: the World of Life, 6th ed., Harper Collins Publishers, 1992, p. 840.

[2] P. O. Heller, Life. The Science of Biology, 3rd ed., p. 574.

[3] L. S. Costanco, Physiology, 3rd ed., 2006, pp. 612.

[4] I. Fox, Ph.D., Human Physiology, 2nd ed., p. 691.

[5] M. Klavins, O. Nikodemus, V. Silins, V. Mellecis, M. Vircovs, K. Āboltina, "Environment science," LU Academic Publisher, 2008, p. 599, ISBN 978-9984-825-09-7.

[6] A. Peters, G. Hoek, K. Katsouyanni, "Understanding the link between environmental exposures and health: does the exposome promise too much?" J Epidemiol Community Health, Feb. 2012, vol. 66 (2), pp. 103-105. http://dx.doi.org/10.1136/jech-2011-200643

[7] J. Vencloviene, R. Babarskiene, R.I. Kubilius, J. Stasionyte, "The effect of solar-geomagnetic activity during and after admission on survival in patients with acute coronary syndromes," International Journal of Biometeorology, Aug 2014, vol. 58, issue 6, pp. 1295-1303. http://dx.doi.org/10.1007/s00484-013-0725-0

[8] V. Rozhkov, N. Belisheva, A. Martynova, S. Soroko, "Psychophysiological and cardiohemodynamic effects of solar, geomagnetic, and meteorological factors in humans under the conditions of the arctic region," Human Physiology, Jul 2014, vol. 40, issue 4, pp. 397-409. http://dx.doi.org/10.1134/S0362119714040124

[9] "Ultravioletais starojums un tā ietekme uz cilvēka veselību," Atlants, [Online]. Available: http://www.atlants.lv/referats/ultravioletais-starojumsun-ta-ietekme-uz-cilveka-/674868/

[10] A. Ahlbom, M. Feichting, "Electromagnetic radiation," Environmental Polution and Health British Medical Bulletin, 2003, vol. 68, pp. 157-165. http://dx.doi.org/10.1093/bmb/ldg030

[11] "Health Criteria 137. Electromagnetic Fields," Environmental Internationtional Programme on Chemical Safety, WHO, Geneva, 1993.

[12] M. Papailioua, S. Dimitrova, E. S. Babayevc, H. Mavromichalakia, "Analysis of Changes of Cardiological Parameters at Middle Latitude Region in Relation to Geomagnetic Disturbances and Cosmic Ray Variations," American Institute of Physics, 2009. http://dx.doi.org/10.1063/1.3322548

[13] M. Piňosová, M. Andrejiová, E. Lumnitzer, "Analysis of clinical signs of noise exposure on human health in plants with high exposure to noise," International J. of Engineering, T.XI, 2013, Fascicule, ISSN 1584-2665.

[14] A. Blinovs "Atomelektrostaciju ietekme uz apkārtējo vidi," [Online]. Available: http://www.atlants.lv/prezentacija/atomelektrostaciju-ietekmeuz-apkartejo-vidi/435190/

[15] O. Coskun, "Magnetic resonance imaging and safety aspects," Toxicology \& Industrial Health, 05/01/2011, vol. 27, Issue 4, pp. 307-313.

[16] A. K. Jha, A. M. Singh, B. Shetye, S. Shah, A. Agrawal, N. C. Purandare, P. Monteiro, V. Rangarajan, "Radiation safety audit of a high volume Nuclear Medicine Department," Indian Journal of Nuclear Medicine, Oct-Dec 2014, vol. 29, Issue 4, pp. 227-234.

[17] A. A. Kolodynski, V. V. Kolodynska, "Motor and Psychological Functions of Scool Children Living in the Area of the Skrunda Radio Location Station in Latvia," The Science of the Total Enviroment, 1996, vol. 180 , no. 1 , pp. 87-93.

[18] A. A. Kolodynski, V.V. Kolodynska, "Electromagnetic Fields: Legislation Research in Latvia," Proc. Latvian Academy of Sciences, 2006, vol. 60 , no. 1.

[19] Y. Grigorjev, Mobile "Telecommunication: Radiobiological Issues and Risk Assesment," Proc. Latvian Academy of Sciences, 2006, Sec.B, vol. 60 , pp. 6-10.

[20] I. Markovica, Z. Markovics, "Selection of parameters for differential diagnosis," Cybernetics and Diagnostics, Riga, 1972, vol. 5, pp. 37-45. (in Russian).

[21] J. Osis, J.A. Gelfandbein, Z. Markovics, N. Novozilova, "Diagnostics on Graph models," Transport, Moscow, Transport, 1991, p. 245 (in Russian)

[22] J. Osis, J. Grundspenkis, Z. Markovics, "Topological Modelling of Complex Heterogenus System. Theory and Aplications," Riga Technical University, 2012, pp. 407. (in Latvian).

[23] M. G. Hendall, J. D. Gobbons, Correlation methods, 5th ed., Arnat, London, UK, 1990, pp.114-121.

[24] A. Voronin, The expert data processing method, Kiev, Naukova Dumka, 1974, pp. $97-103$. 
Zigurds Markovics, Dr. hab. sc. ing. is a Professor (since 1993) with the Institute of Computer Control, Automation and Computer Engineering, Faculty of Computer Science and Information Technology, Riga Technical University.

$\mathrm{He}$ is the author of 148 scientific publications and 3 monographs.

His research interests are: computer control systems, artificial intelligence systems, robotics.

$\mathrm{He}$ is a Member of Latvian Association of Professors and Latvian Association of Scientists.

Address: Meza Str. 1/4, Riga, LV-1007, Latvia.

E-mail: Zigurds.Markovics@rtu.lv
Ieva Markovica received the degree of $D r$. sc. med. in 1990. She is a Docent and a Researcher with the Faculty of Computer Science and Information Technology, Riga Technical University, and with the Research Institute of Cardiology, University of Latvia.

He research interests are: cardiovascular diseases epidemiology, risk factors and prevention, structural modeling, expert systems for diagnostic and therapy selection.

She is the author of more than 100 publications: 2 monographs, papers in international journals and conferences.

She is a Member of European and Latvian Society of Cardiology and a Member of Latvian Society of Hypertension.

Address: Meza Str. 1/4, Riga LV-1007, Riga, Latvia.

E-mail: imarka@inbox.lv

Zigurds Markovičs, Ieva Markoviča. Parametru kopas izveide apkārtējās vides iedarbības izpētei uz slimības gaitu

Darbs veltīts zinātniskās izpētes problēmām, kad jānoskaidro ārejāas vides faktoru ietekme uz veselu organismu vai slimības gaitu. Viena no pirmajām problēmām kādus organisma parametrus mērīt faktoru iespaida noskaidrošanai. Visvienkāršāk ir mērīit vai nu visus, ko iespējams izmērît, vai arī praksē lietotus mērījumus. Tomēr rezultāts būs labāks, ja mēerāmo parametru kopa tiks mērktiecīgi atlasīta, ievērojot parametru efektivitāti, saiti ar slimības skartajām apakšsistēmām, nodrošinot slimību visu patoǵenētisko izpausmju pārklājumu. Autori piedāvā šim nolūkam izmantot slimības patoǵenēzes topolog̣isko modelēšanu, modeḷa formalizētu apstrādi, parametru novērtěšanu, sarindošanu un mērāmo parametru kopas izvēli ar tabulas pārklājuma metodi.

Зигурдс Маркович, Иева Марковича. Создание совокупности параметров для определения влияния внешней среды на течение заболевания. Работа посвящена проблемам исследования влияния факторов окружающей среды на протекание того или иного заболевания. Одной из проблем является проблема выбора эффективного множества измеряемых параметров живого организма. Установлено, что лучшие результаты будут достигнуты, если целенаправлено отобрано множество параметров, с учетом тесных связей этих параметров с патогенетическими процессами при конкретном заболевании, и обеспечено полное покрытие этих процессов. Авторы предлагают такой метод отбора парметров на базе топологического моделирования патогенетическиих процессов организма. 